\title{
IDENTIFIKASI SISWA BERMASALAH DENGAN MENGGUNAKAN METODE ROUGH SET (STUDI DI SMA N 4 PARIAMAN)
}

\author{
Masrizal, Musthafa Haris Munandar \\ Fakultas Sains dan Teknologi, Universitas Labuhanbatu \\ $\underline{\text { masrizal120405@gmail.com }}{ }^{1}$ harismunandaaar@gmail.com ${ }^{2)}$
}

\begin{abstract}
Abstrak
Sekolah merupakan pembahasan segudang ilmu dari dasar pendidikan yang akan dapat dikembangkan oleh guru kepada siswa-siswi yang terdapat pada sekolah mereka sebagai penuntut ilmuan baik secara imtek maupun secara iptaq terhadap dari kepihakan sekolah tersebut.pada pengidentifikasian disekolah siswa dapat merupakan pola pikir untuk kemajuan terhadap diri dari masa depanya karena situasi terhadap gangguan atau lingkungan dapat mempengaruhi siswa-siswi diluar lingkungan sekolah karena ini dalam pergerakan pola pendidikan siswa diwajibkan belajar 12 tahun lamanya untuk memerlukan kewajiban proses belajar. Untuk itu diperlukan dari penelitian ini menggunakan proses metode data mining pada sekolah SMA N 4 Pariaman. Didalam data mining terdapat metode Rough Set yang akan menganalisa serta mengaljabarkan seluruh ke sulitan tingkah laku terhadap siswa-siswi disekolah tersebut. maka dapat diproses Pengetahuan tersembunyi tersebut dapat dicari menggunakan metode Rought Set. Penelitian dilakukan dengan menganalisa pengidentifikasian siswa disekolah di kasus yang dilakukan pada siswa yang terlibat dalam kasus yang tertera oleh badan pihak guru BK disekolah pada tahun ajaran 2018 sekolah SMA N 4 Pariaman Desa Naras Hilir Kota Pariaman. Setelah dilakukan analisa lanjutan menggunakan Rought Set, diketahui bahwa sekolahyang memiliki sekolah ISN adalah sekolah berstandar internasional dari kota pariaman sumatera barat. Dari penelitian ini dapat diketahui bahwa Rought Set dapat digunakan sebagai salah satu metode dalam menganalisa sebuah pengidentifikasian dalam perlakuan terhadap siswa disekolah
\end{abstract}

\section{Kata kunci : Data Mining, Rough Set, Nama Siswa identifikasi.}

\section{PENDAhULUAN}

Penelitian mengenai penerapan data mining menggunakan algoritma rough set sudah banyak dilakukan oleh orang-orang yang berada dibidang informasi teknologi atau pada bidang lainnya, sesuai pola perkembangan penemuan ilmu pada saat sekarang mengalami perkembangan yang semakin berkembang, sehingga banyak penemuan teknologi baru. Data mining adalah proses untuk menemukan pengetahuan, pola, dan informasi yang menarik dari sekumpulan data berukuran besar melalui proses deskriptif, pemahaman dan prediksi dengan menggunakan suatu model atau algoritma (Dedi. H dan Hartono, 2016).

SMA N 4 Pariaman merupakan sekolah yang berstandar internasional dibidang dunia pendidikan sekolah ini memiliki jumlah siswa yang terdapat baik secara program ips maupun ipa sehingga sekolah tersebut diketahui dikala masyarat.Mengenai sekolah 
tersebut salah satu bentuk satuan pendidikan formal yang menyelenggarakan sekolah menengah atas sebagai lanjutan jenjang pendidikan dari atau bentuk lain yang sederajat. Disekolah ini dapat menentukan kualitas hasil dari berdasarkan kriteria yang sudah ditentukan oleh Unit Produksi SMA N 4 Pariaman. Sebagai kajian bersama mengenai hubungan konsep diri dan motivasi pengaruh terhadap pelanggaran siswa yang terlibat dalam masalah agar dapat memperhatikan siswa tersebut.

Sesuai dengan pola hasil penelitian yang saya temukan pada sekolah dimana penulis dapat menemukan hasil dari rancangan metode yang saya jelaskan pada sebuah sekolah dalam menentukan proses tingkah laku siswa atau disebut macam kasus yang dilakukan oleh siswa yang terlibat dalam bentuk kasus tersebut oleh karena itu penelitian dapat menentukan pola data yang akan dijadikan dalam sebuah bentuk laporan yang akan dilakukan dalam proses penelitian tersebut sehingga pola penelitian yang saya jadikan dalam bahan pengolah penelitian yang dirancangkan dalam metode rough set berkaitan oleh sistem data mining tersebut.

Sesuai dengan proses pada metode rough set ini penulis dapat menguasai dimana pada penelitian sehingga untuk dapat memberikan bentuk gambaran tentang yang dapat diusulkan dalam penelitian yang akan dapat dibahas sesuai dengan langkah proses data mining berdasarkan langkah penelitian yang akan dilakukan tersebut Berdasarkan latar belakang permasalahan yang ada tersebut,

\section{LANDASAN TEORI}

Knowledge Discovery in Database (KDD) Knowledge Dicovery In Database(KDD) merupakan salah satu tahapan penting didalam proses Knowledge Discover in Database (KDD).Terminologi dari KDD dan data mining adalah berbeda. KDD adalah keseluruhan proses di dalam menemukan pengetahuan yang berguna dari suatu kumpulan data sedangkan data mining adalah salah satu tahapan pada KDD dan fokus pada upaya untuk menemukan pengetahuan yang berguna dengan menggunakan algoritma.

Pada data proses Kdd merupakan Teori Rough set dikembangkan oleh Zdzislaw Pawlak pada awal tahun delapan puluhan. Teori ini muncul karena adanya Rough pada suatu himpunan, dimana dalam teori Rough set, data dapat direpresentasikan dalam dua sistem yaitu system informasi dan system keputusan yang ada pada(Karmila Suryani, 2016).

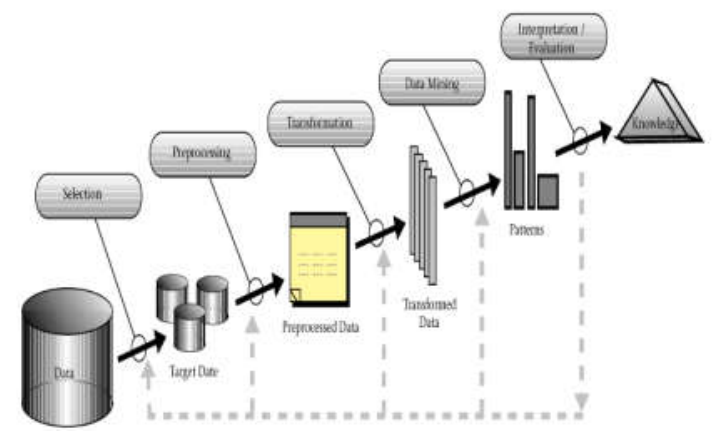

Gambar 2.1.Proses dalam Knowledge Data Discovery

Berdasarkan gambar diatasdidefinisikan merupakan salah satu bagian proses Knowledge Discovery in Database (KDD) yang bertugas untuk mengekstrak pola atau model dari data dengan menggunakan suatu algoritma yang spesifik. Adapun proses KDD 
sebagai berikut (Ginanjar, A.M dan Riana,. 2012):

1. Data Selection :pemilihan data dari sekumpulan data operasional perlu dilakukan sebelum tahap penggalian informasi dalam KDD dimulai.

2. Preprocessing :sebelum proses data mining dapat dilaksanakan, perlu dilakukan proses cleaning dengan tujuan untuk membuang duplikasi data, memeriksa data yang inkonsisten, dan memperbaiki kesalahan pada data, seperti kesalahan cetak (tipografi). Juga dilakukan proses enrichment, yaitu proses "memperkaya" data yang sudah ada dengan data atau informasi lain yang relevan dan diperlukan untuk KDD, seperti data atau informasi eksternal.

3. Transformation :yaitu proses coding pada data yang telah dipilih, sehingga data tersebut sesuai untuk proses data mining. Proses coding dalam KDD merupakan proses kreatif dan sangat tergantung pada jenis atau pola informasi yang akan dicari dalam database.

4. Data mining :proses mencari pola atau informasi menarik dalam data terpilih dengan menggunakan teknik atau metode tertentu.

5. Interpretation / Evaluation :pola informasi yang dihasilkan dari proses data mining perlu ditampilkan dalam bentuk yang mudah dimengerti oleh pihak yang berkepentingan. Tahap ini merupakan bagian dari proses KDD yang disebut dengan interpretation. Tahap ini mencakup pemeriksaan apakah pola atau informasi yang ditemukan bertentangan dengan fakta atau hipotesa yang ada sebelumnya atau tidak.
Sehingga dapat diketahui apa itu KDD sendiri dari kutipan penelitian yang diambil dari berdasarkan jurnal yang dikutip seperti yang diketahui yaituKnowledge Discovery in Database (KDD) adalah proses menentukan informasi yang berguna serta pola-pola yang ada dalam data. Informasi ini terkandung dalam basis data yang berukuran besar yang sebelumnya tidak diketahui dan potensial bermanfaat

\section{METODOLOGI PENELITIAN}

Proses penelitian dibab III ini merupakan suatu bentuk sistem pola kerja seseorang penelitian yang dapat membentuk seperti langkah tujuan penelitian pada bab ini akan dijelaskan metode penelitian. Metode penelitian ini bertujuan untuk membantu proses penelitian atau disebut sebuah karya penulis dalam menyelesaikan penelitian agar penelitian menjadi terarah dan juga dapat berguna untuk orang bagi pembaca tesis dari penelitian tersebut.

Pengertian dari metode Data Mining adalah data yang dapat menghasilkan dalam bentuk sebuah laporan yang melebihi data yang besar. Data Miningini suatu metode yang dapat membantu seorang penelitian dalam mengambil keputusan terhadap data yang diolah keaplikasi rosetta sehingga dapat memutuskan hasil laporan yang telah didapatkan dalam sistem sehingga untuk bisa diambilan keputusan penting.

Penelitian juga dapat membentuk atau menciptakan suatu metode yaitu mengenai metode Rough Set pada data mining tersebut. Metode penelitian adalah suatu cara teknik yang sistematik untuk menemukan suatu hal berdasarkan suatu metode ilmiah. Oleh karena 
itu diperlukan kerangka pemikiran sebelum memulai penelitian tentang data mining dengan menggunakan algoritma rough set.

\section{HASIL DAN PEMBAHASAN}

\section{Tahapan Analisa}

Analisa dapat dilakukan agar penemuan masalah yang ada, dapat diketahui penyebabnya, sehingga dari tahapan analisa tersebut didapatkan suatu bentuk dalam pecaham masalah.Dari hasil analisa tersebut penulis merumuskan masalah yang terdapat pada identifikasi siswa yang bermasalah disekolah SMA N 4 pariaman. Hal ini tentu akan menyulitkan jika tanpa menggunakan sebuah metode.

Mengimplementasikan software rosetta, menguji hasil dan menarik kesimpulan. Guna memudahkan analisa data, maka dibuat tahapan pengolahan data dengan menggunakan algoritma rough set seperti pada gambar 4.1 dibawah ini.

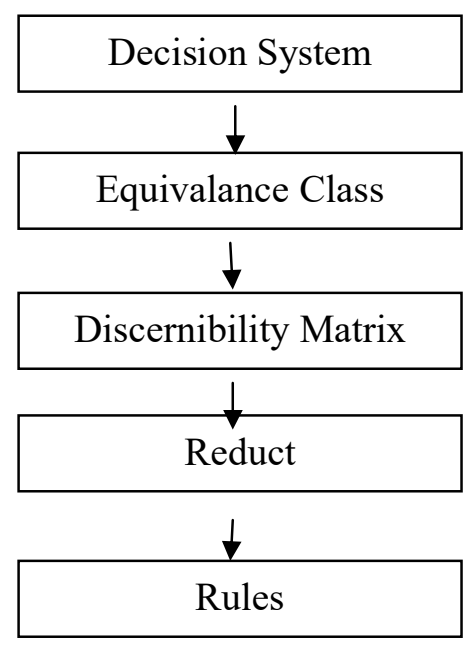

Gambar 4.1. Langkah Algoritma Rough Set

\section{V.Implementasi \& Hasil}

Bab ini merupakan tahapan dimana akan dibahas tentang implementasi dan pengujian metode menggunakan sebuah metode Rough set. Dalam tahapan ini akan dijelaskan dengan menggunakan Software Rosetta dan serta hasil dari menganalisa metode terhadap permasalahan yang ada pada bab sebelumnya.

\section{Pendahuluan}

pada tahapan implementasi ini peniliti diharuskan melakukan penempatan aplikasi yang sedang dibangun kepada sebuah sistem, tujuan implementasi ini adalah untuk mengetahui sejauh mana aplikasi pada sistem dapat digunakan dan apa saja keterbatasanketerbatasan yang ada pada aplikasi tersebutpembahasan ini merupakan pola penelitian saya yang dapatdibahas mengenai terhadap item dari pengimplementasian sistem Software Rosetta proses menganalisa data sehingga dapat menentukan dalam bentuk rule. Sehingga perhitungan disesuaikan menggunakan aplikasi Software Rosetta dalam pengujian hasil.

\section{Data Pengujian Implementasi Sistem}

Proses data diperoleh dari penulis yang didapatkan dari pihak sekolah SMA N 4 Pariaman dimana penulis dapat memasukan keseluruhan data tersebut supaya implementasi berjalan dengan baik dan sesuai dengan yang diharapkan, maka suatu rencana implementasi perlu dibuat terlebih dahulu.Rencana ini dimaksudkan untuk mengatur waktu yang dibutuhkan selama tahap implementasi.

Implementasi program merupakan realisasi dari hasil rancangan yang telah 
dibuat pengujian data menggunakan software yang telah tersedia dalam bentuk excel sehingga dapat menentukan kepastian yang akan diujikan dalam proses pengimplementasian uji sistem pada gambar 5.1 .

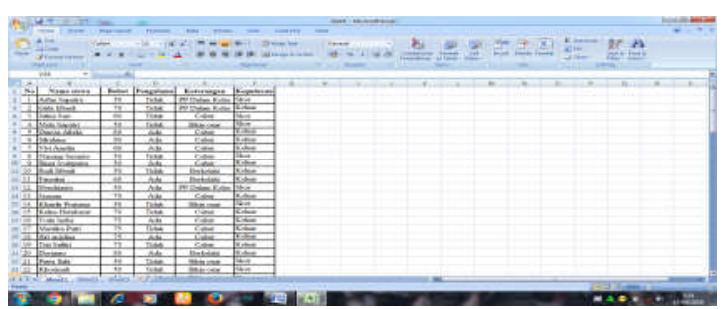

Tahapan Aplikasi Sistem Rosseta

Proses melakukan pembentukan secara ini penelitian dapat mengimplemntasikan laporan dari sekolah SMA N 4 Pariaman sesuai yang dibentuk software rosseta juga dapat mengimplementasikan kedalam metode rough set ini dapat dilihat digambarkan melalui beberapa tahap.

1. Pembukaan aplikasi Software Rosetta Software Rosetta digunakan untuk mengimplementasikan algoritma rough set untuk mendapatkan rule yang tersembunyi. Langkah pertama, pilih dan klik shortcut Software Rosetta yang ada pada desktop atau klik tombol windows untuk mencari aplikasi Software Rosetta kemudian klik, maka muncul lah tampilan awal aplikasi dilihat pada gambar 5.1.

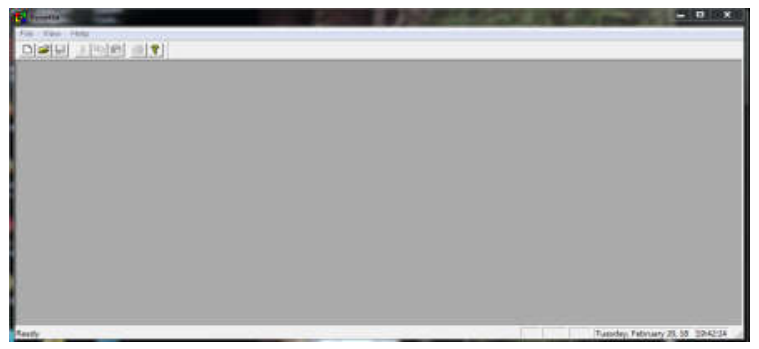

Gambar 5.2Tampilan Awal SistemRosetta
Untuk memulai menggunakan software Rosetta,langkah pertama yang dilakukan adalah mengklik menu File yang berada pada kiriatas aplikasi, kemudian pilih new atau menekan tombol new yang terletak di bawah menu File, maka muncul tampilan awal program, dimana pada tampilan tersebut terdapat 2 buah menu, yaitu menu StructuredanAlgorithms, maka akan muncul tampilan seperti gambar 5.2.

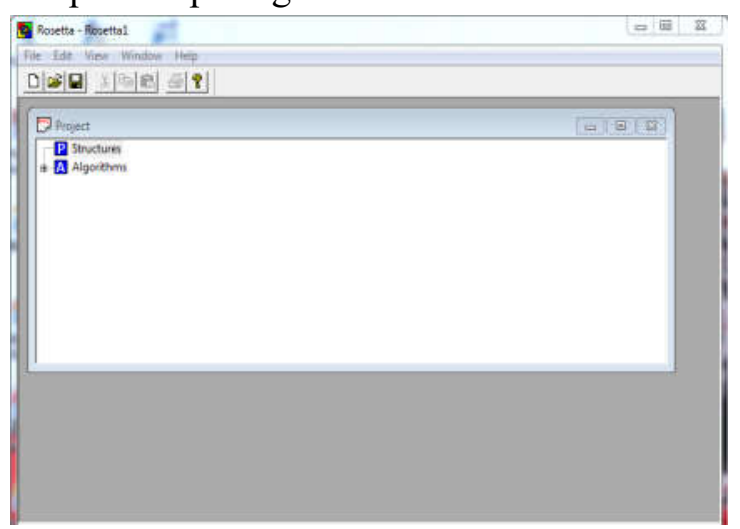

\section{Gambar 5.3 TampilanNew Project Rosetta}

2. Membuat ODBC atau database

Untuk melakukan pengolahan data, perlu membuat database (ODBC) dengan mengarahkan kursor ke Structure kemudian klik kanan pada Structure dan pilih ODBC, maka akan muncul tampilan seperti gambar

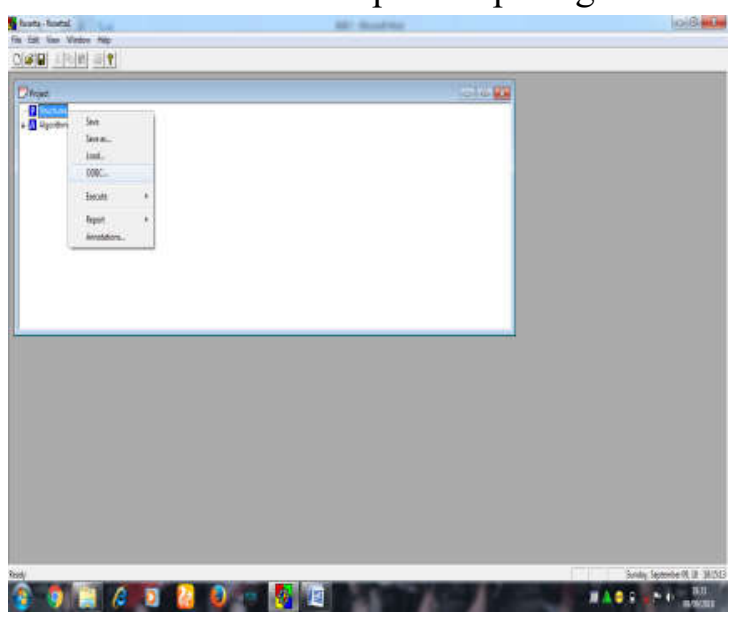

Gambar 5.4Import Filepada Rosetta 


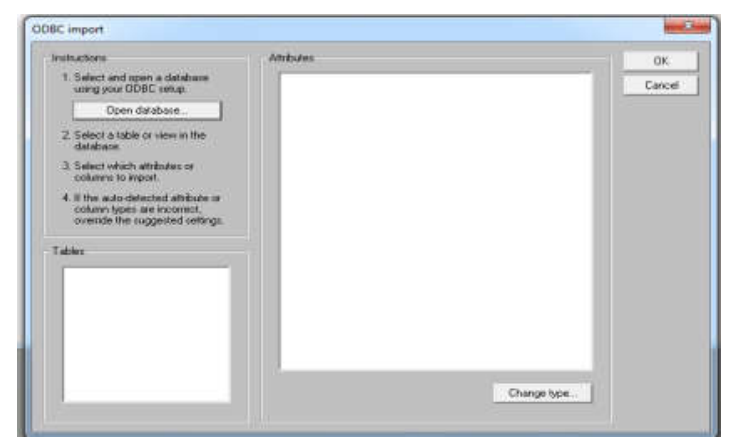

Gambar 5.5Membuat ODBC (Database)

3. Memilih Database dan Membuat Database

Setelah muncul tampilan seperti gambar 5.4, langkah selanjutnya adalah mengkliktombol "Open Database"untuk memilih database yang akan dilakukan pengolahan dengan mencari database tersebut sesuai dengan tempat penyimpanannya seperti pada gambar.

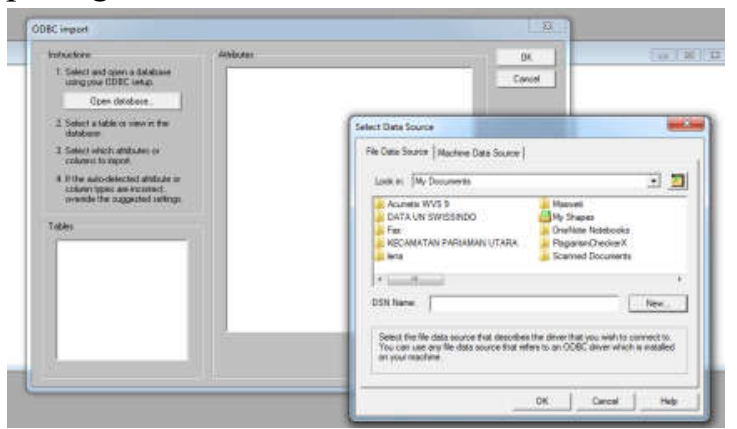

Gambar 5.6 Memilih Database yang TelahTersedia

Jika database belum ada, maka langkah yang dilakukan adalah membuat database baru dengan mengklik tombol new pada tampilan "Select Data Source"dan muncul tampilan “Create New Data Source”.Setelah itu, lakukan pemilihan format file yang akan dijadikan sebagai database untuk dilakukan pengolohan.Kemudian pilih tipe database-nya Microsoft Excel Driver (*.xls, *.xlsx, *.xlsm, *.xlsb) dan kliktombol next seperti yang terlihat pada gambar

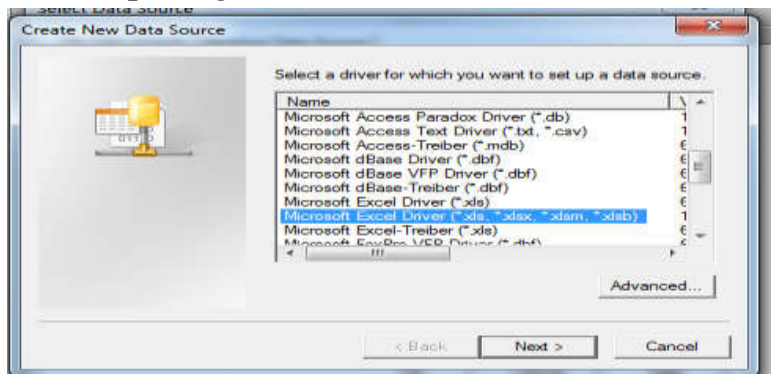

\section{Gambar 5.7Pilihan Create New Data \\ Source}

Setelah tipe database dipilih kemudian kliktombol "browse" dan keluar tampilan untuk membuat filedatabase, kemudian klik tombol "save", lanjutkan dengan mengklik tombol "next"'kemudian

tombol "Finish"dan "OK”.

Langkah selanjutnya adalah mengkliktombol "new"dan pilih file mana yang akan dijadikan sebagai database, lalu klik tombol "OK”. Jika database sudah muncul pada kolom DSN New, maka klik tombol "OK" seperti pada gambar

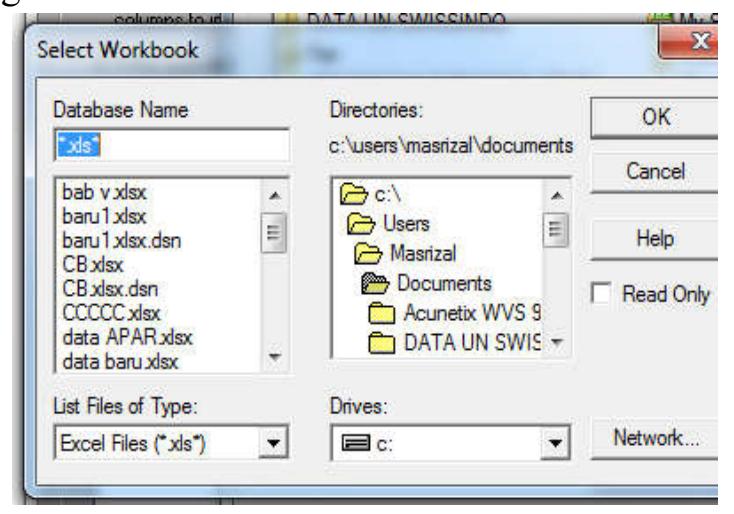

\section{Gambar 5.8 Memilih File Database}

\section{Memilih Databases}

Memilih database lalu dipilih browse sehingga tampil memilih file yang akan dilakukan serta keluarlah bagian file yang digunakan lalu oc. Seperti pada gambar. 


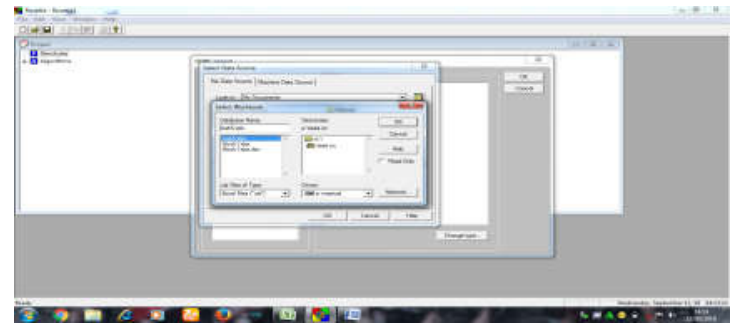

Gambar 5.9 Memilih FileData

5. Memilih field yang digunakan

Dalam memilih field yang akan diolah, field nama tidak dimasukkan kedalam pengolahan data. Karena jika tetap dipilih maka field nama akan ikut diolah oleh software.Kemudian klik tombol "OK”'dan muncul hasil import data ke program Rosetta sehinga proses ini terlihat pada terdapat sepertiyang terlihat pada gambar

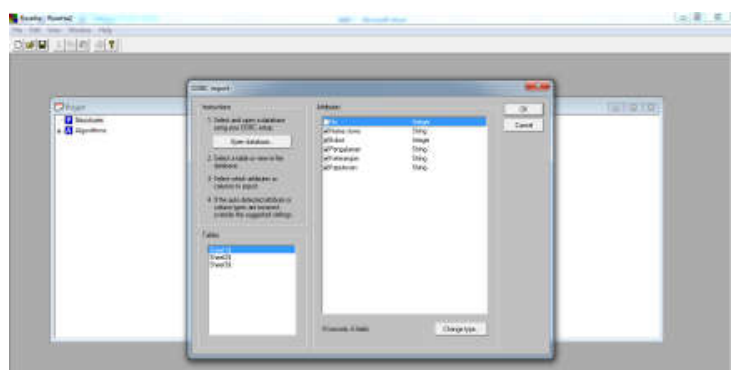

\section{Gambar 5.10 Memilih Field yang} Digunakan

6. Dynamic Reduct

pada dynamic reduct ini harus mempersipkan database sehingga terdapat pada sheets klik kanan akan timbul reduce kemudian diambil dynamic reduct tersebut kemudian klik oke.

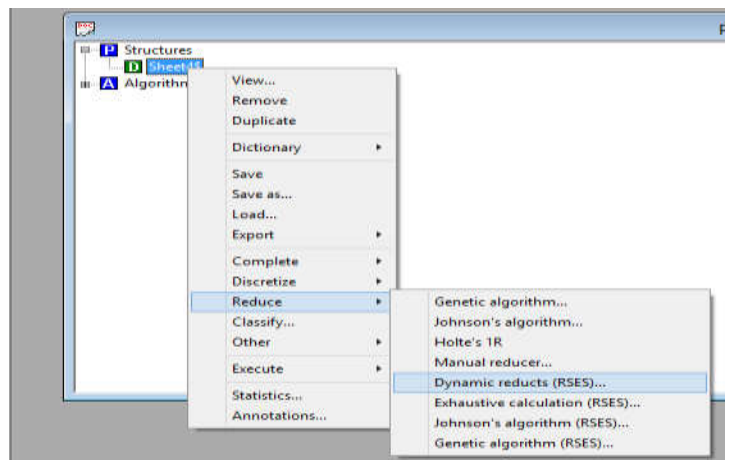

\section{Gambar 5.11Proses Reduct Pada Rosetta}

7. Hasil Dynamic Reduct

Langkah selanjutnya masih dalam tahapan yang sama proses ini juga dapat melakukan dynamic reduct sehingga akan muncul hasil reduct yang dilakukan. Hasil tersebut sama dengan jumlah reduct yang diperoleh dari sebelumnya sesuai proses sistem.

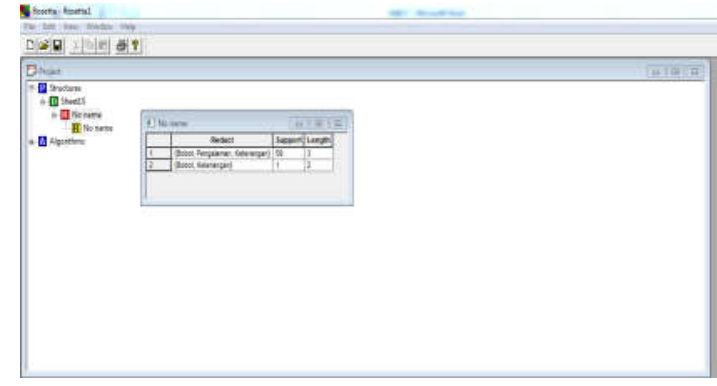

Gambar 5.12 Hasil Dynamic Reduct

8. Generate Rules

Pada tahapan selanjutnya yaitu generate rules dimana bentuk pencarian generate rules ini hanya dilakukan klik kanan sehingga muncul berbagai instrukmen lalu dipilih generate rules klik kemudian klik ok. 


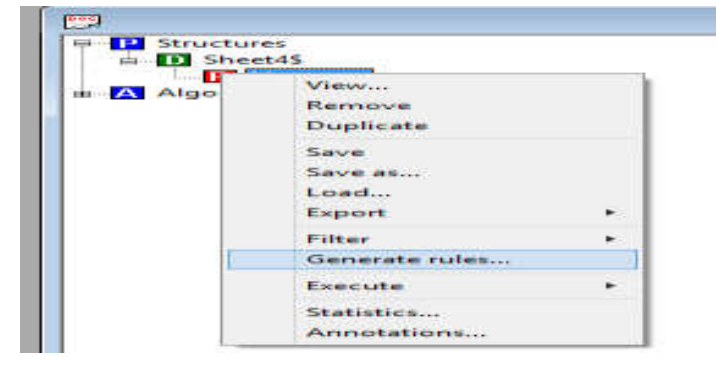

Gambar 5.13Folder Generate Rule

9. Hasil Generate Rules

Pada melaksanakan generate rulesrule akan mengeluarkan hasil sesuai kode pengaplikasian data. Dengan mengklik generate rules maka hasil rule ini dapat dilihat pada gambar.

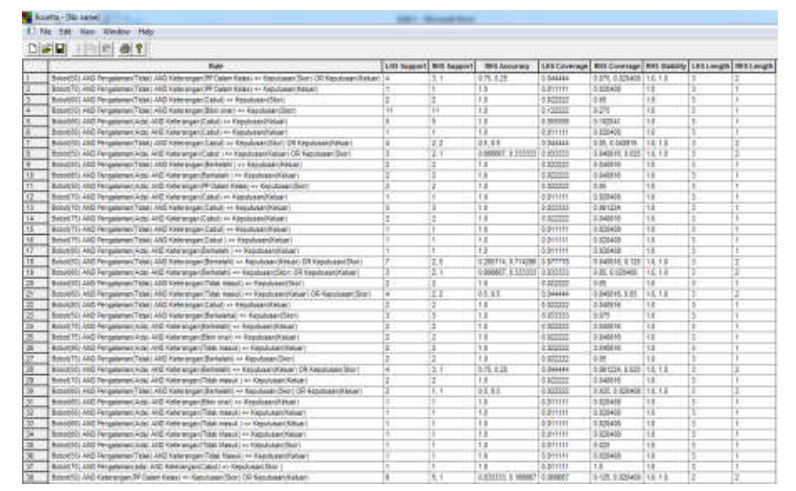

Gambar 5.14 Hasil Generate Rules

\section{4 Analisa Hasil Pengujian}

Berdasarkan hasil pengujian menggunakan Teknik Rough Set atau Aplikasi Rosseta dengan menggunakan seluruh data pada sistem rosseta dimana hasil yang didapatkan pada identifikasi siswa bermasalah dengan menggunakan 90 data yang diambil secara keseluruhan dengan menggunakan aplikasi Rosetta, dimana pada pencarian aplikasi rosetta menggunakan 90 data tersebut yang didapatkan oleh penulis Maka Sehingga ditemukan hasil Reductntya yang terdapat 2 buah hasil reduct dimana ialah :
1. Bobot (EC3), Pengalaman (EC4), Keterangan (EC5)

2. dan jenis selanjutnya Bobot (EC3) Keterangan (EC5)

Setelah hasil reductnya didapatkan maka generate rulenyadapat dihasilkan rulenya 64 Rule yang didapatkan oleh sistem rosetta dalam aturan keputusan (decision rule) yang terbentuk dengan menggunakan seluruh data siswa tersebut maka dapat penulis menganalisa dalam proses Aplikasi Rosetta mampu membantu dalam proses pencarian hasil keputusan dari sistem aplikasi rosetta tersebut.

\section{KESIMPULAN}

Berdasarkanpenelitian yang penulis lakukan pada Sekolah SMA N 4 Pariaman, maka penulis dapat menarik serta kesimpulan bahwa sistem pendukung keputusan yang didukung suatu metode Rough Set dan akan bermanfaat sekali dalam pengambilan keputusan

Atas analisa dan pembahasan yang penulis lakukan pada pengolahan sistem pendukung keputusan dalam penggunan metode Rough Set maka penulis dapat mengambil kesimpulan sebagai berikut :

1. Perancangan sistem dengan menggunakan metode rough set dapat digunakan untuk mengetahui siswa yang terlibat dalam pelanggaran disekolah sehingga didapatkan hasil dalam keputusan oleh siswa tersebut.

2. Penulis dapat merancangkan metode rough set serta menganalisa 
data siswa yang teridentifikasi masalah disekolah tersebut.

3. Aplikasi Rosetta mampu mengatasi pembahasan dalam proses pencarian hasil keputusan yang teridentifikasi pada siswa disekolah.

4. Hasil dari penelitian ini adalah menghasilkan suatu Rules (aturan) yang dimanfaatkan untuk mengambil keputusan dimasa yang akan datang dengan cara melakukan pengolahan data yang didapatkan disekolah SMA N 4 Pariaman sehingga pengextraan data dilakukan dengan menggunakan program aplikasi Rosetta.

\section{SARAN}

Berdasarkan hasil penulisan yang telah dilakukan adapun saran dari penulis adalah sebagai berikut:

1. Penulis mengharapkan agar hasil dari penelitian ini dapat menjadi lebih baik dari sebelumnya sesuai dengan hasil proses dari menganalisa penelitian sendiri pada sekolah SMA N 4 Pariaman.

2. Penulis dapat melakukan pengujian rough set dalam perumusan aritmatika dan pengalgoritmaan sesuai dalam bentuk laporan secara benar serta menganalisa.

3. Penulis hanya dapat melakukan penelitian ini yang bisa dipahami serta menjadi referensi pada metode rough set pada penelitian identifikasi disebuah sekolah SMA N 4 Pariaman tersebut.

Penulis dapat membuat hasil laporan berupa dalam bentuk aplikasi rosseta yang telah dijadikan dalam laporan analisa identifikasi pada siswa tersebut

\section{DAFTAR PUSTAKA}

Abdullah.D, dkk, 2015. "Implementasi Metode Rough Set Data Nasabah Potensial Mendapatkan Pinjaman".Jurnal Prosiding Seminar Ilmiah Nasional Teknologi Komputer Vol.1, Oktober 2015; p. 1-8.

Andika Prajana, 2016. "Penerapan Teory Rough Set Untuk Memprediksi Tingkat Kelulusan Siswa Dalam Ujian Nasional pada SMA NEGRI 5 KOTA BANDA SMA" .Journal of Islamic Science and Technology Vol.2,No.1 Juni 2016; p.75-88.

Ermayanti Astuti, 2015, "Metode Rough Set Dalam Pengurusan Perizinan Tempat Usaha (Studi Kasus: Badan Pelayanan Terpadu Dan Penanaman Modal Dumai)". Jurnal Seminar Nasional Informatika Vol.2, Maret 2015 ; p. 462-466.

Fitri Maidarli, 2012, "Sistem Prediksi Stok Obat Dengan Menggunakan Metode Rough Set (Studi Kasus : Apotek Bangkinang-Riau)".Jurnal

Pengembangan Teknologi Informasi Dan Ilmu Komputer Vol.2 No.7 Januhari 2012; p.34-77. 
Ginanjar, A.M dan Riana, 2012, "Penerapan Data Mining Untuk Mempredikasi Kriteria Nasabah". Jurnal Komputer Dan Informatika Vol.1, Maret 2012 ; p. 53-57.

Geojantoro, R., dkk, 2017, "Penerapan Metode If-Then dari Rough Set Theory dalam Menangani Kecelakaan Lalu Lintas di Kota Samarinda Tahun 2016". Jurnal Eksponensial Vol.8.No.2 November 2017; p.145150.

Hartama Dedi dan Hartono, 2016, “Analisis Kinerja Dosen STMIK IBBI Dengan Menggunkan Metode Rough Set".Jurnal Seminar Teknologi Informasi Dan Multhimedia Vol.5, Februari 2016; P. 49-54.

Ilmawati, 2014, "Penerapan Teknik Artificial Intelligent Rough Set Untuk Mendukung Keputusan Pada Proses Pemerikasan Kondisi Penjualan Barang Pada Toko Silungkang ART Center Padang". Jurnal KomTekInfo Fakultas Ilmu Komputer Vol.1, No.1, Juni 2014; p. 51-62.

Karmila Suryani, 2016, "Prediksi Peluang Kelulusan Mahasiswa PTIK Dalam Uji Kompetensi Microsoft Office 2010 Menggunakan Teori Rough Set”. Jurnal Teknosi Vol.2, No.1 April 2016; p. 1-10.

Listiana Nila., dkk. 2013, "Implementasi Algoritma Rough Set Untuk Deteksi
Penangganan Dini Penyakit Sapi”. Jurnal Teknik Informatika Vol.2 Januhari 2013; p. 67-73.

Muhammad Jamaris., 2017, "Implementasi Metode Rough Set Untuk Menentukan Kelayakan Bantuan Dana Hibah Fasilitas Rumah Ibdah". Jurnal Inovtek Polbeng Seri Informatika Vol.2 No.2 November 2017; p.161170.

Muhammad Romi. S, 2017, “Aplikasi Rough Set Untuk Memprediksi Calon Anggota Kelompok Programming". Jurnal Mantik Penusa Vol.17 No.1 Juni 2017; p;121-126.

Yanti Yusman, 2015, "Metode Rough Set Untuk Memimilih Tipe Rumah Idaman Sesuai Dengan Selera Konsumen Pada PT. Rizki Pratiwi Mulya” Jurnal Teknika Vol.3 No.1 Juni 2015; p 52-58.

Yulianti dan Salmidi, 2016, "Metode Rough Set Untuk Menganalisa Problematika Guru Dalam Menggunakan Media Pembelajaran Berbasis Computer". Jurnal Teknologi Dan Sistem Informasi UNIVRAB Vol.1 No.1 Januhari 2016; p 19-24. 